\title{
Alternative teaching practices for inclusive education
}

\author{
Celia Corchuelo Fernández ${ }^{1 \mathrm{a}}$, and Carmen María Aránzazu Cejudo Cortés ${ }^{1}$ \\ ${ }^{1}$ University of Huelva, Faculty of Educational Sciences, March 3 Avenue, 21071 Huelva, Spain
}

\begin{abstract}
The research that we carried out in this article tries to demonstrate how the good practices that the teachers of the Second Chance Schools have in their centers (significant learning, propinquity and support) are effective pedagogical tools to reduce rates of school failure and dropout and, in other cases, to eliminate those two hurdles that the education system has and which is exacerbated in certain social contexts. Basically, this research is articulated in a theoretical framework, a research process or methodological framework, results from that research and the establishment of conclusions.
\end{abstract}

Keywords: Inclusive education, alternative teaching, teachers

\section{Introduction}

This article go deep into school failure during the secondary education stage, with special emphasis in the context of social exclusion, due to the marked incidence of conditioning factors leading to poor performance, non-achievement of objectives, repetition of course and early school-dropout in adolescents between the ages of 12 and 15 at risk of exclusion, led to a possible insertion which will not be achieved due to not be qualified for it.

In order to turn this situation back, on the one hand we find studies [5] that analyze the possible causes of the increasing rate of schooling flaws and school failure in a poor area where the main objective is the labour integration of young people. Today generation has been beaten by early school leaving and the absence of degree or qualification given as a result the swap from the marginal area to the area with good social and economic prospects, which definitely brings, according to this study, is a new brand community that moves from reflection to action and accompanies adolescents in their transition from School to work.

On the other hand, we find projects like «Alternativas al fracaso escolar, prácticas pedagógicas para la inclusión» [4] centered on the research carried out by an interdisciplinary and interinstitutional team of teachers, linguists and psychologists, who went deep in the study of the causes and indicators of the phenomenon of school failure in contexts of social exclusion, with the aim of reversing it. In this study, special importance was given to pedagogical alternatives based on diversification and the proposal of a new

a Corresponding author: celia.corchuelo@dedu.uhu.es; carmen.cejudo@dedu.uhu.es 
school model high social vulnerability environment, the so-called school with a community teacher program.

\section{Significant learning, propinquity and support}

It is inevitable to focus on the secondary stage in dealing with school failure, because it is the educational period in which its consequences become evident, although it has also been proven that their roots can be found in primary school. In most cases, due to the chance of joining the labor market and quitting schoolwork which the student, may not feel very comfortable, it is in the last cycle "or the last two years of compulsory secondary education" when students begin to "walk on the tightrope", considering early school dropout.

Due to this reason, there are three basic foundation that all students should have in mind if he is planning to join the Second Chance School. Firstly, to support those students who achieve their academic success [9]. Secondly, in order to achieve meaningful learning there must be a predisposition of the student to this type of assimilation and finally, there must be some kind of material that is potentially significant (so as to speak, that can be related in a non-arbitrary way with the cognitive structure of the student or with preconceptions).

The research about the theory of meaningful learning which was done a year before helps to elucidate the cases in which the assimilation is not significant, but repetitive or mechanical [10]. First, the author highlighted two main characteristics of meaningful learning whose absence cannot be just given: the receptive attitude or predisposition to learn significantly, and the preexistence of concepts of anchorage in the cognitive structure that can serve as a basis or contrast to the new information.

Based on the observations in the different secondary schools where support and reinforcement programs were developed, good teaching practices materialize when all the professionals who are part of the program are integrated in their framework, remaining in direct and continuous contact with students at risk of exclusion, evaluating results and introducing the changes they deem necessary, planning new practices and scheduling the teaching-learning process [8].

Teachers who are fully involved in these tasks are promoting educational engagement and, in this specific context, a series of values that include citizen education and solidarity learning.

\section{Objective}

The objective is to carry out a research process in which the teaching practices performed by a group of teachers of a second chance school are exposed.

Thus, this study aims to expose students to an alternative. In this sense, the research intends to present other options in which it is understood that each student is different, authentic, unique and disrespectful and that each of them can and have the capacity of achieving any goal that they want to accomplish.

\section{Method}

The methodological framework describes and shows the design of the research as a case study centered on the Institute of Secondary Education of Andalusia. In order to carry out this research, we have opted for a descriptive method, used to collect, organize, synthesize, present, analyze, generalize and conclude the results that arise from the different information collection instruments. This method involves the collection and systematic 
presentation of data to present a clear idea of a particular phenomenon or situation, evaluating the proposed objectives.

\subsection{Sample}

We have carried out our research based on the descriptive method from a multi-method approach, understood as a research strategy in which more than one method is used for the investigation of the same phenomenon or object of study. Their use is justified due to their flexibility to adapt to the demands of understanding and explanation of our reality, improving the research processes and products. That is the reason why, we have used the qualitative method through the interview and the quantitative method by means of the observation record.

The sample is based on twenty subjects, which were selected from a total of thirty subjects and reflects an excess number for such a case study.

\section{Results}

Regarding the results, on the one hand, an analysis of the interviews has been carried out. as well as a description of the families of codes and the frequency of occurrence in the interviews. Code families refer to the nomenclature that brings together a group of categories that have resulted from the analysis of the interviews conducted to the twenty subjects belonging to this research. The classification of families has been based on the model of social competence for students at risk of school failure [1], [11], [3], being the codes the descriptors of roles, profiles, skills, interactions, ideas, ways of acting, strategies, interventions, organization of the center.

On the other hand, a descriptive analysis of the observations. Using the conceptual model extracted from the principles that some authors have called "alternative instruction" [6], [7], or "authentic instruction" [2]. The underlying model identified after factor analysis identifies three factors: significant learning, proximity and support.

In order to identify possible relationships between variables, in the analysis of the observations, we proceed to perform an analysis of Spearman correlations, given that these are qualitative variables of an ordinal nature. This analysis allows to identify the significant correlations that are discussed below. In general, the analysis of correlations corroborates, in part, the underlying model.

That is, a strong direct correlation $(\mathrm{r}=0.481, \mathrm{p}<0.01)$ was found between the variable "substantive conversation, substantive with his/her classmates" and "teacher-student relationship", both variables are identified with the denominated factor "proximity".

Secondly, a direct correlation $(\mathrm{r}=0.254, \mathrm{p}<0.05)$ between "student participation" and "connection with students' experiences outside school" was verified, both variables being aspects of the so-called factor "significant learning". In this sense, "material coherence" correlates directly $(r=0.186 ; p>0.05)$, but not significantly with "student participation", the third variable of the "meaningful learning" factor.

In the variable "reinforcement of personal aspects", it correlates directly and significantly $(r=0.248, p<0.05)$ with "teacher-student relationship". It also maintains an inverse but not significant correlation with "student participation", which is reasonable evidence.

Finally the bivariate analysis of interviews and observations. We combine the data from the encodings of the interviews with those coming from the observations. Codes from both category systems are combined into the same database. The objective is to identify if there are relations between the teacher profile, codified through the interviews, and the didactic actions, codified through the observations. As already indicated, observed behaviors are 
recorded on an ordinal scale with values ranging from 1 to 4 , while codes related to the teaching profile will be presented in the database on a nominal scale indicating presence or absence of the code, in this case of teaching trait.

For the combination of product codes of different instruments (interview and observation) a contrast of means is made, identifying as independent variables the interview codes that define teacher attitudes, while the dependent variables are those that define the didactic action in the classroom of teachers. Therefore, the following attitudes are considered as independent variables: discipline-affection balance, accompaniment, empathy and involvement.

Likewise, as dependent variables, the following are considered: Material coherence, connection with student experience, substantial conversation, student participation, higher order thinking skills, teacher-student relationship, reinforcement of personal aspects and leadership.

\section{Conclusions}

We have tried to know the educational responses that teachers display in Second Chance Schools through a case study focused on secondary school in Andalusia, but whose conclusions could be extended to other centers with similar characteristics. To this end, we have compiled a model of educational attention that is put into practice with students characterized by a trajectory of school failure and the risk of social exclusion. In our study, we have compiled and defined good teaching practices emphasizing those that in this particular center are obtaining positive results and have again attracted the education system to boys and girls who had abandoned it or at least perceived it with large doses of Skepticism, getting them not to resign, give themselves a second chance and find a motivation that opens new horizons and personal and educational expectations.

About:

\subsection{Pedagogical practice}

\subsubsection{Significant learning}

- Teachers of Second Chance Schools deal in depth with key concepts or ideas, basic to teaching, presenting topics in an integral, non-fragmented and offline.

- Students seem to respond to this work methodology, since when applied properly, they focus on the task to be developed, significantly decreasing attention loss and disruptive behaviors.

\subsubsection{Proximity}

The preponderant attitude in the Second Chance Schools is to maintain a strong relationship of trust between the teaching staff and the majority of the students. There is also often a very positive support. This is reflected in the conversations held between teachers and students, which allow establishing friendly relations and are capable of generating mutual trust.

\subsubsection{Support}

Teachers of Second Chance Schools use positive reinforcement, working on selfesteem/motivation and personality characteristics of students. At the same time, specific 
leadership characteristics are observed in these schools, since most of the teachers maintain, as a form of leadership, a certain balance between authority and democratic consensus.

\subsection{Pedagogical alternatives from Second Chance Schools}

\subsubsection{Motivation, one of the keys}

In order to face this situation, the teacher starts from the idea of understanding motivation as one of the keys in the teaching-learning process, since its lack causes a good part of the school failure and the premature abandonment of the classrooms, besides generating conflicts within them.

\subsubsection{Teacher-student relations}

Dialogue and closeness, supported by the action of the center's psychological and pedagogical team, make it possible to diagnose gaps, as well as detecting the strengths and weaknesses of each student separately, and in this way to design and plan the individual and collective didactic strategy. Therefore and despite the levels of self-esteem and motivation are low, there will always be a small door to enter and "awaken" the students of the disengagement, making him see that he can change his career and take charge of his own growth as a person through the education.

\subsubsection{Importance of class climate}

To cope with this situation, an suitable class atmosphere will generally begin; establishing limits during the first weeks of the course, keeping them intact throughout the academic year, providing rules that are visualized in the classroom in panels or walls, maintaining a relationship of empathy and trust with students, training in reciprocity relationships.

\subsubsection{Presence in the tutorials}

In this regard, the subjects of the sample consider detrimental and counterproductive to strengthen the habits of reciprocity and mutual respect especially in Secondary and in educational contexts in which diversity becomes fundamental, the change of tutors and teachers that annually takes place.

\section{References}

1. Comer, J. P. The Yale-New Haven Primary Prevention Project: A follow-up study. Journal of the American Academy of Child and Adolescent Psychiatry, 24, 154-160 (1985)

2. D'Agostino, F. Interpretación y hermenéutica. Revista de fundamentación de las Instituciones Jurídicas y de Derechos Humanos, 35, 39-56 (1996)

3. Dumas, J. E., Prinz, R. J., Smith, E. P., Laughlin, J. The EARLY ALlianCE Prevention Trial: An Integrated Set of Interventions to Promote Competence and Reduce Risk for Conduct Disorder, Substance Abuse, and School Failure. Clinical Child and Family Psychology Review, 2, 1, 37-53 (1999)

4. Gabbiani, B., y Kachinovsky, A. El fracaso escolar. Prácticas pedagógicas para la inclusión. (2010). Retrieved from http://www.psico.edu.uy/sites/default/files/cursos/pseducacional_alternativas_al_fracaso_\%20escolar.pdf on 16.03.2017 
5. Gallardo, M.C., y Nieto, C. El fracaso escolar y la exclusión social en una zona de transformación social, zona sur de Sevilla: causas, actuaciones, estrategias y perspectivas futuras de intervención social. RevistaRets, 14, 11-117 (2009)

6. Knapp, M., Cambridge, P., Thomason, C., Beecham, J., Allen, C., Darton, R. Care in the Community: Challenge and Demonstration. Avebury, Aldershot. (1992)

7. Newman, F. M., Wehlage, G.G. Five standars for authentic instruction. EducationalLeadership, 50, 87, 15-19 (1993)

8. Ritacco, M.J., y Amore, F.J. Buenas prácticas educativas ante el fracaso escolar en los programas de apoyo y refuerzo en contextos de exclusión social. Revista de currículum y formación del profesorado, 15, 118-137 (2011)

9. Rodríguez, M. La teoría del aprendizaje significativo: una revisión aplicable a la escuela actual. Revista Electrònicad'Investigació i InnovacióEducativa i Socioeducativa, 3, 29-50 (2011)

10. Rodríguez, M.L. La teoría del aprendizaje significativo en la perspectiva de la psicología cognitiva. Barcelona: Editorial Octaedro (2010)

11. Smith, E.P., Connell, C. M., Wright, G., Sizer, M., Norman, J. M., Hurley, A., Walker, S. N. An ecological model of home, school, and community partnerships: Implications for research and practice. Journal of Educational and Psychological Consultation, 8, 339-360 (1997) 